\title{
ファン付き作業服と作業時間帯が建設作業員の生理・心理反応に及にす影響 建設現場における実態調査 その 2 \\ EFFECT OF VENTILATED WORK WEAR AND WORKING SCHEDULE ON PHYSIOLOGICAL AND PSYCHOLOGICAL RESPONSES OF CONSTRUCTION WORKERS
}

No.2 Actual investigation at active construction sites

葉 原浩平*1, 山崎 慶太*2, 菅 重夫*3, 小林 宏一郎*4, 濱田靖弘 ${ }^{* 5}$, 高 橋 直 ${ }^{* 6}$

\section{Kouhei KUWABARA, Keita YAMAZAKI, Shigeo SUGA, Koichiro KOBAYASHI, Yasuhiro HAMADA and Nao TAKAHASHI}

\begin{abstract}
We investigated the relationship between the thermal environment at a construction site and the physiological and psychological responses of workers wearing/not wearing ventilated work wear (VWW). The overall, chest and forearm skin temperatures of the workers not wearing VWW were significantly higher than those of workers wearing VWW. To clarify the effects of VWW and working schedules on body weight loss (BWL), the rate of BWL was simulated based on the evaporation rate according to a regression formula of measured data in an artificial chamber. Increased BWL during the late compared with the early shift causes dehydration in the afternoon.
\end{abstract}

\author{
Keywords : Ventilated work wear, Construction worker, Skin temperature, Evaporative rate, Rate of \\ bode weight loss, Working schedule \\ ファン付き作業服，建設作業員，皮膚温，蒸発密度，体重減少密度，作業時間帯
}

\section{1.はじめに}

近年、暑熱対策として冷却服の利用が拡大している。冷却服には、 氷冷式 1)や PCM 式 2)の冷却ベスト、強制換気式の冷却服 3)などいく つかのタイプがあり、主に人工気候室での被験者実験やサーマルマ ネキンを利用した実験 4)により、その有効性が検証されてきた。建 設現場では、それらの中でも軽量性と持続性に優れた強制換気式冷 却服であるファン付き作業服（Ventilated Work Wear；以下 VWW と称す）の利用が急拡大している。Chan ら 5)は、PCM とファンを 組み合わせたハイブリッド冷却ベストを開発し、実際の建設現場で その有効性を検証しているが、実際の現場における冷却服の有効性 に関する研究はまだ少ないようである。

著者らは、2016 年 7 8 月に屋内外の建設現場において実測を行 い、ファン付き作業服（VWW）や作業時間帯等の要因が作業員（屋 内：内装工・配管工、屋外：型枠大工・鉄筋工）の生理 - 心理反応 に及ぼす影響を評価した ${ }^{6}$ 。心理反応では VWW の効果が認められ たが、温熱環境の日・時変動と、職種毎・個人毎に活動量の差が異 なることもあり、生理反応における VWW の効果は、4 パラメータ
のみ（屋外：平均皮膚温、耳内温、歩行作業、屋内：ボード・配管 作業）で認められた。また、屋外工事の作業員の平均皮膚温は、午 後の方が有意に高值を示すのに対し、屋外の MRT は午後に有意に 低かったので、パス解析による型枠大工の「暑さ感」が午後に増す のは、温熱環境の影響ではないと考えられた。脱水等の影響が考え られるが、発汗量は測定しなかったため、評価できなかった。

次に気温・活動量・服装の条件を統制した条件下での VWW の効 果を評価するために、2017 年 5 6 月に人工気候室を用いて被験者 実験を行った 7)。現場を想定した環境(気温 $29,34^{\circ} \mathrm{C}$, 相対湿度 $50 \%$ ) で、被験者（鉄筋工・型枠大工）に模擬作業を行わせ、VWW 着用、 非着用時の生理・心理反応を測定した。現場で測定されなかった裸 体時体重減少量と着衣時体重減少量、両者の差から着衣残留汗量を 算出した。その結果、気温 $34^{\circ} \mathrm{C}$ では、VWW が平均皮膚温を約 $0.4^{\circ} \mathrm{C} 、$ 舌下温を約 $0.1^{\circ} \mathrm{C}$ 抑制し、着衣残留汗量と心拍数も有意に低值を示 した。一方、蒸発した汗、呼気に含まれる水分と捉える着衣体重減 少量にはVWW の有無で有意な差がなかった。この結果から、 「VWW の有無と気温に依存して着衣残留汗量が有意に変化し、心拍

\footnotetext{
*1 釧路工業高等専門学校 准教授·博士 (工学)

*2 (株)竹中工務店技術研究所 部長付 · 博士 (工学) 岩手大学理工学部 客員教授

*3 株竹中工務店東京本店安全環境部 グループリーダー

*4 岩手大学理工学部 教授・博士 (工学)

*5 北海道大学大学院工学研究院 教授·博士 (工学)

*6 千村ネイチャー俱楽部 監事・博士(社会学)
}

Assoc. Prof., Dept. of Creative Engineering, National Institute of Technology, Kushiro College, Dr.Eng:

Assist. to General Manager, Takenaka Research \& Development Institute, Dr.Eng. Visiting Prof. of Iwate University

Takenaka Corporation, Head Office, Tokyo, Safety and Environment Dept. Prof., Dept. of Systems Innovation Engineering, Iwate University, Dr.Eng. Prof., Graduate School of Engineering, Hokkaido Univ., Dr.Eng.

Chimura Nature Club, Ph.D. in Sociology 
数が増減する。」という有意なパスモデルを作成した。しかし、人工 気候室内は日射のない静穏状態であることや、移動が少ないため作 業量も実際よりも少ないと考えられ、実際の建設現場での体重減少 量を測定し、VWWの有効性を検証する必要があると考えられる。

そこで本研究では、人工気候室実験で確認された VWW が平均皮 膚温、部位別皮膚温に及ぼす効果を実際の現場で検証すること、前 報 6)の建設現場では測定できなかった体重減少量を測定し、VWW や作業時間帯等の要因が体重減少量に及ぼす影響を検討することを 目的とする。まず気温と平均皮膚温や部位別皮膚温の関係、平均皮 膚温と心理反応の関係について、VWW が及ぼす影響について検討 する。さらに、人工気候室実験でVWW の効果が顕著に確認された 着衣残留汗量 7)を含みかつ現場では測定が困難な裸体時体重減少量 (発汗量十不感蒸散量) を、人工気候室実験から得られた回帰式を 用いて、着衣時体重減少量と飲水量から推定する。推定された体重 減少量について、気温をパラメータとして VWW の効果を検証する とともに、舌下温、平均皮膚温、心拍数、活動量が VWW 有無と時 間帯により変動するかを二要因の分散分析を用いて評価する。既報 6)で提示された課題である、実際の建設現場で、作業員の熱ストレ ス、脱水状態が時間帯に依存するか詳細に検証する。

\section{2. 実測 - 解析方法}

\section{1 実測方法と場所}

\subsection{1 実測場所・日時と被験者・作業内容}

実測日時・実測場所を Table 1 に示す。本実測は、東京都新宿区 小川町の $\mathrm{RC}$ 造 8 階建ての建設現場で、2017 年 8 月 $3 \sim 8$ 日のうち 5 日間実施した。夏季の作業現場の実例として、屋外の建設現場で実 際に作業を行っている鉄筋工や型枠大工等を対象とした実測を行っ た。鉄筋工、型枠大工の作業状況を Fig.1 に示す。(a)に示すように 型枠大工は 6 階での柱・梁型枠建て込み作業、(b)に示すように鉄筋 工は地上での梁配筋作業に従事していた。被験者属性をTable 2 に 示す。被験者は健康な男性 10 名である。各日 5 名に VWW を着用 させ、残り 5 名は非着用とした。この際、武職以外は同日に各職種 で必ず着用・非着用の両状態が用意できるようにVWWを分配した。 以降、着用日と非着用日を交互に設けた。

本研究は、岩手大学の人を対象とする医学系研究倫理審査委員会 の承認（第 201703 号、平成 29 年 6 月 19 日付）を得て実施した。 被験者には、実験前に予め実験内容を説明し、承諾を得ている。

\subsection{2 温熱環境と人体の生理・心理反応}

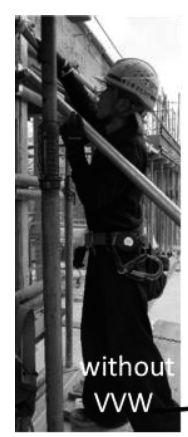

(a) Form worker

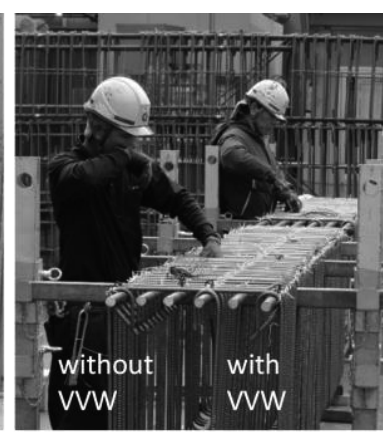

(b) Rebar placer
Fig.1 Working condition of each construction worker
温熱環境と人体の生理反応の測定項目・測定機器を Table 3 に示 す。環境側・人体側の測定共にそれぞれの計測間隔は 1 分とした。 温熱環境測定機器は、建設作業に支障が無いように、鉄筋工が主に 作業する地上では作業域の端に、型枠大工が主に作業する 6 階では 作業域のほぼ中心位置に設置した（Fig.2）。地上、6 階共に温湿度 1 点 (床上 $1.5 \mathrm{~m}$ )、風速（熱線式 1 点、三杯式 1 点 $($ 同 $2 \mathrm{~m})$ )、灰グ ローブ温 1 点（同 $1 \mathrm{~m} ）$ を測定し、温湿度センサは小型自然通風シ エルター内に固定し、センサへの熱放射を防いだ。6 階測定点では 床上 $1.5 \mathrm{~m}$ の日射計により水平面日射量を、地上測定点では床上 $1 \mathrm{~m}$ の黒色と白色のグローブ温度計の計測值よりグローブに到達する日 射量を測定した。6 階の測定点は、実測初日の 3 日は見通しのきく 風通しの良い場所であったが、2 日目以降周囲の壁が建て込まれ、7 日、8 日は外気が遮断され風通しが悪くなった。

朝の作業開始前に、被験者には心電計（胸バンド）、ボタン型温度 ロガー (4 点: 前腕、胸、大腿前面、下腿前面)、リストバンド型ラ イフレコーダー (左手首) 6)、心拍計（右手首）を装着させた。現 場での作業は基本的に 8 17 時に行われ、休憩を挟んで午前 2 回 (AM1：8:00 10:00、AM2：10:30 12:00)、午後 2 回（PM1： 13:00 15:00、PM2: 15:30 17:00）の 4 回に分けられている。着衣 時体重、飲水量、舌下温、主観申告記入を各作業開始前後に計 8 回 行った。作業中の飲水量はスポーツドリンクを用意し、その減少量 を記録した注1)。平均皮膚温は Ramanathan の 4 部位に基づき、胸 部 $\times 0.3+$ 前腕部 $\times 0.3+$ 大腿部 $\times 0.2+$ 下腿部 $\times 0.2$ として算出した。 主観評価として、暑さ感、快適感、口渇感を作業開始時と終了時に 申告させた注2)

なお、本報の分析には型枠大工 4 名 $(\mathrm{A}, \mathrm{B}, \mathrm{C}, \mathrm{D})$ と鉄筋工 3 名 ( $\mathrm{O}, \mathrm{P}, \mathrm{Q})$ のデータのみを使用することとした。これは、被験者 $\mathrm{R}$ (窵職) の作業が多岐にわたり他の職種と作業時間帯が大きく異な っていたことと、被験者 $\mathrm{E}, \mathrm{O}$ （土工）の作業場所は屋内が多く温熱 環境が鉄筋工・型枠大工とは異なっていたためである。VWW の着 用と非着用日は Table 5 の通りである。VWW 着用は延べ 18 名、

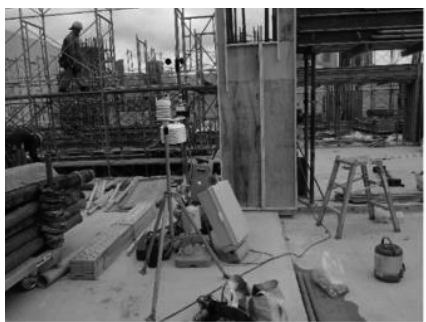

(a) $03 / 08 / 2018$

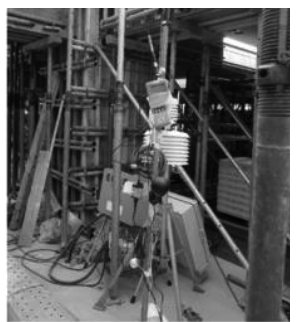

(b) $08 / 08 / 2018$ (a) On the 6th floor for form worker

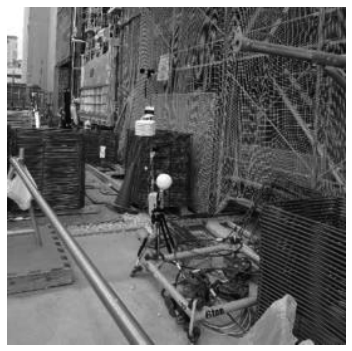

(b) On the ground for rebar placer

Fig.2 Equipments for measuring thermal environment 
VWW 非着用は延べ 17 名のデータを使用する。温熱環境は、午前・ 午後 2 データずつとなるように当該時間帯の平均值を計算した。

\section{2 解析方法}

黒色と白色のグローブ温から環境グローブ温と人体に到達する日 射量を算出する 8)。環境グローブ温とは, 気温と長波長放射の影響 を考慮したグローブ温を表し, 以下の式(1)で算出される。また人体 に到達する日射量は，式(2)で算出される。

$$
\begin{gathered}
t_{g l e}=\frac{\alpha_{b} t_{g l, w}-\alpha_{w} t_{g l, b}}{\alpha_{b}-\alpha_{w}} \\
I_{\text {sun }, g l}=\frac{\left(t_{g l, b}-t_{g l e}\right) h_{g l}}{\alpha_{b}}
\end{gathered}
$$

ここで, $t_{g l e}$ :環境グローブ温度 $\left[{ }^{\circ} \mathrm{C}\right], t_{g l, b}, t_{g l, w}$ : 黒色, 白色グローブ温 度 $\left.{ }^{\circ} \mathrm{C}\right], \alpha_{b}, \alpha_{w}$ : 黑色, 白色グローブ温度計の表面日射吸収率 $(=0.96$,

Table 1 Schedule and place

\begin{tabular}{c|c}
\hline Schedule & 3rd, 4th, 5th, 7th and 8th, August, 2017 \\
\hline \multirow{2}{*}{ Place } & Shin-ogawacho, Shinjuku-ku, Tokyo \\
& RC, 8F, Building construction field \\
\hline
\end{tabular}

Table 2 Human subjects

\begin{tabular}{c|c|c|c|c}
\hline No. & Age & $\begin{array}{c}\text { Height } \\
{[\mathrm{m}]}\end{array}$ & $\begin{array}{c}\text { Weight } \\
{[\mathrm{kg}]}\end{array}$ & Type of occupation \\
\hline A & 68 & 1.68 & 66 & Form worker \\
B & 51 & 1.70 & 62 & Form worker \\
C & 20 & 1.60 & 49 & Form worker \\
D & 50 & 1.70 & 82 & Form worker \\
E & 32 & 1.72 & 73 & Earth worker \\
O & 66 & 1.76 & 72 & Rebar placer \\
P & 24 & 1.70 & 51 & Rebar placer \\
Q & 28 & 1.68 & 66 & Rebar placer \\
R & 30 & 1.72 & 79 & Scaffold worker \\
S & 16 & 1.68 & 84 & Earth worker \\
\hline
\end{tabular}

\begin{tabular}{|c|c|}
\hline Electrocardiogram & WHS-1 (Union Tool Corp.) \\
\hline Skin temp. & Thermoclon SL (KN Lab.) \\
\hline METs & Life Recorder (A \& D Corp.) \\
\hline Pulse rate & A360 (Polar Electro) \\
\hline Sublingual temp. & $\begin{array}{c}\text { Electronic Thermometer } \\
\text { (Terumo Corp.) }\end{array}$ \\
\hline $\begin{array}{l}\text { Weight、 } \\
\text { water intake }\end{array}$ & GP-100K (T\&D Corp.) \\
\hline Air temp. & \multirow{2}{*}{ TR-72 (T\&D Corp.) } \\
\hline Relative Humidity & \\
\hline Wind velocity & $\begin{array}{c}6533 \text { (Kanomax Japan Inc.) } \\
\text { 200-WS01B (Field Pro) }\end{array}$ \\
\hline Solar radiation & SP-110 (Apogee Inst.) \\
\hline Globe temp. & $\begin{array}{c}\text { 150mm } \varphi \text { (Black and White) } \\
40 \mathrm{~mm} \varphi \text { (Gray) }\end{array}$ \\
\hline
\end{tabular}

Table 3 Measuring instruments

\begin{tabular}{|c|c|c|c|}
\hline & $\begin{array}{l}\text { Thermal } \\
\text { sensation }\end{array}$ & $\begin{array}{l}\text { Comfort } \\
\text { sensation }\end{array}$ & $\begin{array}{l}\text { Thirsty } \\
\text { Sensation }\end{array}$ \\
\hline 3 & Very hot & $\begin{array}{c}\text { Very } \\
\text { uncomfortable }\end{array}$ & Very thirsty \\
\hline 2 & Hot & Uncomfortable & Thirsty \\
\hline 1 & Slightly hot & $\begin{array}{c}\text { Slightly } \\
\text { uncomfortable }\end{array}$ & Slightly thirsty \\
\hline 0 & Neural & Neutral & Not thirsty \\
\hline-1 & Slightly cold & $\begin{array}{c}\text { Slightly } \\
\text { comfortable }\end{array}$ & \\
\hline-2 & Cold & Comfortable & \\
\hline-3 & Very cold & $\begin{array}{c}\text { Very } \\
\text { comfortable }\end{array}$ & \\
\hline
\end{tabular}

Table 4 Sensations 注 2)

Table 5 Schedule of subjects with and without VWW.

\begin{tabular}{|c|c|c|c|c|c|}
\hline & $8 / 3$ & $8 / 4$ & $8 / 5$ & $8 / 7$ & $8 / 8$ \\
\hline With & A, B & C, D & A, B & C, D & A, B \\
VWW & O, P & Q & O, P & Q & O, P \\
\hline Without & C, D & A, B & C, D & A, B & C, D \\
VWW & Q & O, P & Q & O, P & Q \\
\hline
\end{tabular}

0.21)[n.d], $I_{\text {sun, } g}$ : 人体に到達する日射量 $\left[\mathrm{W} / \mathrm{m}^{2}\right], h_{g} j$ グローブ温度計 の総合熱伝達率 $\left[\mathrm{W} /\left(\mathrm{m}^{2} \cdot \mathrm{K}\right)\right]$.

各作業員の皮膚表面積 $\left[\mathrm{m}^{2}\right]$ ，作業時間 $[\mathrm{min}] ，$ 作業時間帯前後に測 定した着衣時体重減少量 $[\mathrm{g}]$ 、各作業時間帯中の飲水量 $[\mathrm{g}]$ から、下式 (3)を用いて蒸発密度 $\left[\mathrm{g} /\left(\mathrm{h} \cdot \mathrm{m}^{2}\right)\right]$ を求めた。なお、現場での着衣時体 重減少量には尿量も含まれている。各時間帯の飲水密度 $\left[\mathrm{g} /\left(\mathrm{h} \cdot \mathrm{m}^{2}\right)\right]$ も、同様に式(4)から求めた。

$$
\begin{aligned}
& \text { 蒸発密度 }=\frac{\text { 着衣時体重減少量 }+ \text { 飲水量 }}{\text { 膚表面積 } \times(\text { 作業時間 } / 60)} \\
& \text { 飲水密度 }=\frac{\text { 飲水量 }}{\text { 膚表面積 } \times(\text { 作業時間 } / 60)}
\end{aligned}
$$

作業時間帯とVWW の有無を独立変数、生理反応（蒸発密度、舌 下温、平均皮膚温、心拍数）を従属変数とし、VWW と時間帯によ って各生理量が変動するか、二要因の分散分析を用いて評価した。 心拍数、平均皮膚温は作業終了前の 30 分間の平均值、活動量は作 業時間帯の平均值とした。

分析にあたり、午前 2 回・午後 2 回を分析対象とした。鉄筋工は 3 名 $(4$ 回 $\times 3$ 人 $\times 5$ 日=のべ 60 名 $) 、$ 型枠大工は 4 名 $(4$ 回 $\times 4$ 人 $\times 5$ 日=のべ 80 名）で分析対象者は合計のべ 140 名であったが、測 定機器の故障などで不具合が生じた型枠大工の 2 回を除いたため、 有効な分析対象者は鉄筋工のべ 60 名、型枠大工のべ 78 名、合計の べ 138 名となった。ただし、心電計（胸バンド）は、作業中に胸部 が圧迫された際にスイッチが切られるなどしてさらに不具合が生じ た型枠大工の 15 回、鉄筋工 14 回をそれぞれ除いたため、有効な分 析対象者は鉄筋工のべ 46 名、型枠大工のべ 65 名、合計のべ 111 名 となった。温熱環境と生理・心理反応の関係について、回帰直線の 差の検定を行った。傾きの平行性の検定を行い、平行であれば切片 の相等性の検定を行った。結果の $\mathrm{p}$ 值は切片の有意差を表す。 
さらに、現場の測定対象となった職種（型朹大工・鉄筋工）が、 人工気候室での実験の職種と一致しているので、人工気候室実験の 結果 7)から, VWW の有無で蒸発密度と裸体時体重減少密度の関係 を求めた。回帰式を用いて、現場の蒸発密度の実測值から、現場で は実測が困難な裸体時の体重減少密度 (発汗密度十不感蒸散密度) を予測し、VWW の効果と時間帯の影響を評価することを試みる。

\section{3. 結果}

\section{1 温熱環境の実測結果}

Fig.3に、地上での温熱環境の実測結果を示す。

Fig.3(a)は、気温の実測結果である。本実測では、8月 3,4 日が 気温 $30^{\circ} \mathrm{C}$ 以下であり、5 日以降は $30^{\circ} \mathrm{C}$ を超える環境であったこと がわかる。Fig.3(b)に、環境グローブ温度の実測結果を示す。気温 と環境グローブ温にほとんど差は見られないが、PM2 の時間帯は環 境グローブ温よりも気温の方が高い。グローブ温度計の設置場所が 影響していると考えられる。 8 日のみ $\mathrm{AM} 2 \sim \mathrm{PM} 2$ は気温よりも環 境グローブ温のほうが $1.5 \sim 2.7^{\circ} \mathrm{C}$ 高い傾向が示された。Fig.3(c)に 人体に到達する日射量の実測結果を示すが、8 日は日射量が多いた め、地物面の温度が上昇していることが原因と推察される。また本 実測期間中は、AM2 の時間帯で到達日射量が最も多いことがわかる。 Fig.3(d)に風速、Fig.3(e)に絶対湿度の結果を示す。風速は午後に弱 くなる傾向にあり、絶対湿度について $3 、 4$ 日は午後にかけて上昇、 5 8 日はほぼ一定の值を示している。

\section{2 平均皮膚温と部位別皮膚温}

気温と平均皮膚温の関係を Fig.4(a)に、気温と部位別皮膚温の関 係を Fig.4(b) (e)に示す。平均皮膚温は、VWW ありよりも VWW なしの方が、高い值を示していることがわかる。回帰直線の差の検 定を行った結果、回帰直線は平行であり、気温に関係なくVWW な しの方が有意に $0.57^{\circ} \mathrm{C}$ 高いことが示された（ $\mathrm{p}<0.001 ） 。$

部位別に見ると、ファンの影響がある胸部では、VWW なしの方 が有意に $1.61^{\circ} \mathrm{C}$ 高く $(\mathrm{p}<0.001) 、$ 同じくファンの影響がある前腕部 でも VWW なしの方が有意に $0.41^{\circ} \mathrm{C}$ 高いことが示された $(\mathrm{p}=0.041)$ 。 人工気候室実験 7)では、胸部では同じく VWW なしの方が有意に高 $<\left(29,34^{\circ} \mathrm{C}\right)$ 、前腕部皮膚温の差は見られなかったが、現場実測 では有意な差がみられた。これは、ファン付き作業服を着用するこ とによる日射遮蔽の影響が考えられる。大腿部 $(\mathrm{p}=0.202)$ と下腿

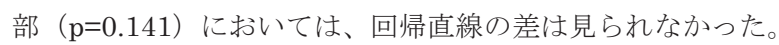

\section{3 平均皮膚温と心理反応の関係}

Fig.5(a)に、平均皮膚温と作業終了時の暑さ感の関係を示す。 VWW の有無で回帰直線の差の検定を行ったが、有意な差は見られ なかった。本現場作業での平均的な作業量は約 $2.2 \mathrm{METs}$ (1.77met) 注3)であり、Fanger による快適時の平均皮膚温は約 $32.8^{\circ} \mathrm{C}$ と推定さ れる。本実測結果を外挿寸ると、約 $31.8^{\circ} \mathrm{C}$ で暑さ感 0 を示しており、 約 $1^{\circ} \mathrm{C}$ 低い值を示した。また、平均皮膚温が概补 $35.4^{\circ} \mathrm{C}$ で非常に 暑い」を申告することが予想された。

Fig.5(b)に、作業終了時の暑さ感と快適感の関係を示している。 暑さ感は「非常に暑い」を申告していても、快適感は「やや不快」 〜「不快」程度であることがわかる。VWW の有無で、回帰直線の 差の検定を行った結果、二直線は平行で、VWW なしの方は不快感 が有意に 0.35 高いことが示された（p<0.05）。VWW があることに

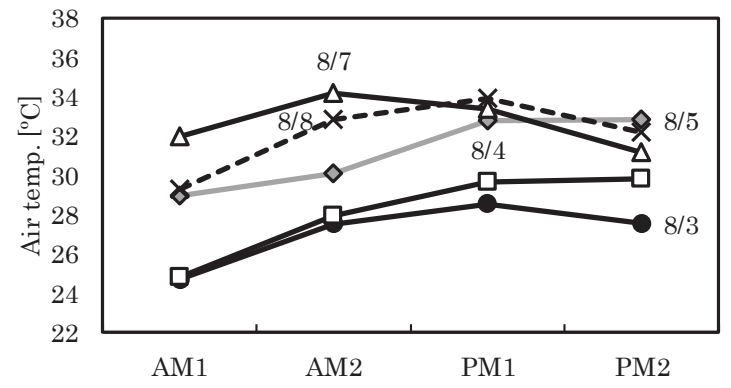

(a) Air temperature

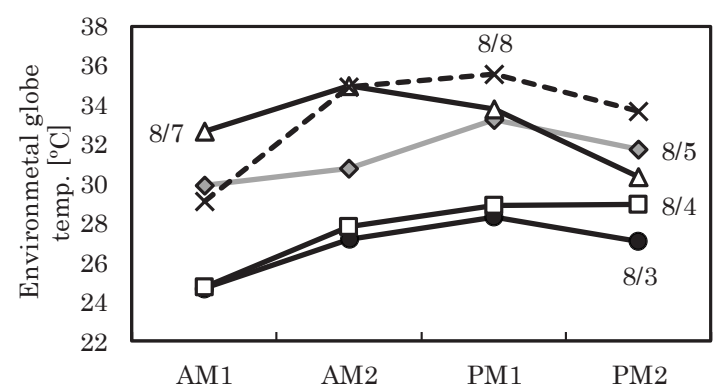

(b) Environmental globe temperature

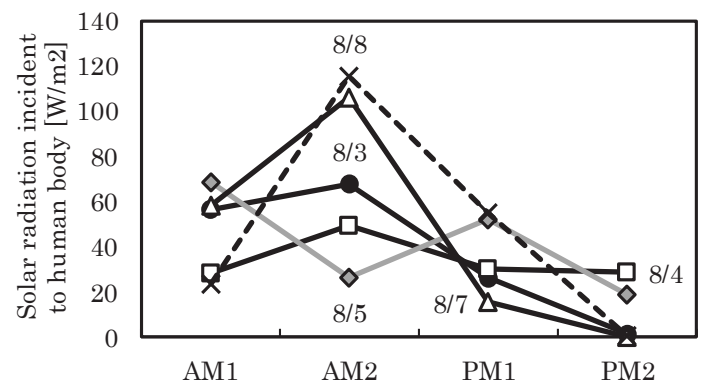

(c) Solar radiation incident to human body

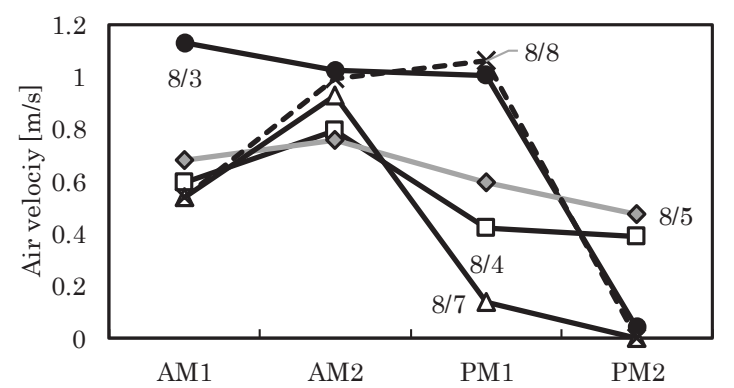

(d) Air velocity

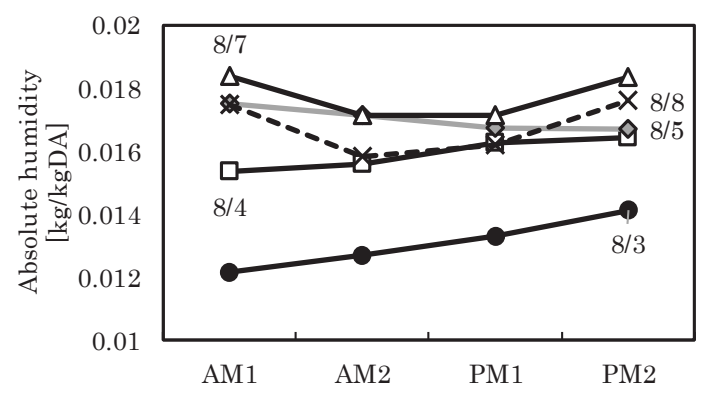

(e) Absolute humidity

Fig.3 Thermal environment at construction site

より同じ暑さ感でも不快感はやや軽減されることが明らかとなった。

Fig.5(c)は、平均皮膚温と作業終了時の口渴感の関係を表している。 概ね平均皮膚温が上昇するほど、口渇感も上昇する傾向が見える。 
VWW の有無で、回帰直線の差の検定を行った結果、切片に有意な 差はなく、同一直線で表せることが明らかとなった。

\section{4 作業時間帯と VWW が生理量に及ぼす影響}

Fig.6 に、VWW と作業時間帯を独立変数とし、飲水密度、蒸発密 度を従属変数とした二要因の分散分析を行った結果を示す。

(a)飲水密度では、VWW と作業時間帯で有意な差が見られなかっ たが、各時間帯でVWW ありはVWW なしより若干小さく、時間帯 では PM2 の飲水密度 $132 \mathrm{~g} /\left(\mathrm{h} \cdot \mathrm{m}^{2}\right)$ が、概水 $100 \mathrm{~g} /\left(\mathrm{h} \cdot \mathrm{m}^{2}\right)$ の他の時 間帯より大きい傾向が認められた。休毠時間を除いた作業時間中の 飲水量は、一人平均約 1,300g/day であった。

(b)蒸発密度では、作業時間帯とVWW の交互作用はなく、作業時 間帯の主効果が有意であり $(\mathrm{F}(1,3)=5.910, \mathrm{p}<.01) 、 \mathrm{VWW}$ には主 効果は認められなかった。そのため、作業時間帯に関して Tukeyの HSD 法(5\%水準)による多重比較を行った結果、AM1（256.8g/(h・ $\left.\left.\mathrm{m}^{2}\right)\right)$ と PM2 $\left(315.2 \mathrm{~g} /\left(\mathrm{h} \cdot \mathrm{m}^{2}\right)\right) 、 \mathrm{AM} 2\left(242.5 \mathrm{~g} /\left(\mathrm{h} \cdot \mathrm{m}^{2}\right)\right)$ と PM2 の間に有意な差が認められた。

Fig.7 に、VWW と作業時間帯を独立変数とし、舌下温、平均皮膚 温、心拍数、活動量を従属変数とした、二要因の分散分析を行った 結果を示す。

(a)舌下温では、作業時間帯とVWW の交互作用はなく、作業時間 帯の主効果が有意であり $(\mathrm{F}(1,3)=2.837, \mathrm{p}<.05) 、 \mathrm{VWW}$ には主効 果は認められなかった。そのため、作業時間帯に関して Tukey の HSD 法(5\%水準)による多重比較を行った結果、AM1 と PM1 の間 に有意な差が認められた。PM1 $\left(36.64^{\circ} \mathrm{C}\right)$ の舌下温は、 $\mathrm{AM} 1\left(36.38^{\circ} \mathrm{C}\right)$ より有意に高值を示した。有意差は認められなかったが、PM2 $\left(36.61^{\circ} \mathrm{C}\right)$ も PM1 と同等に高かった。

(b)平均皮膚温では、作業時間帯とVWW の交互作用はなく、時間 帯の主効果が有意であり $(\mathrm{F}(1,3)=3.899, \mathrm{p}<.05) 、 V W W$ に主効果 が認められた $(\mathrm{F}(1,1)=11.977, \mathrm{p}<.001)$ 。Tukeyの HSD 法(5\%水 準)による多重比較を行った結果、 $\mathrm{AM} 1\left(33.30^{\circ} \mathrm{C}\right)$ の平均皮膚温は、 PM1 $\left.\left(34.05^{\circ} \mathrm{C}\right) 、 \mathrm{PM} 2\left(33.91^{\circ} \mathrm{C}\right)\right)$ より有意に低值を示した。また、 VWW あり $\left(33.47^{\circ} \mathrm{C}\right)$ は、VWW なし $\left(34.05^{\circ} \mathrm{C}\right)$ より有意に低值 を示した。

(c)心拍数では、作業時間帯と VWW の交互作用はなく、VWWに は主効果が認められた $(\mathrm{F}(1,1)=10.135, \mathrm{p}<.01)$ VWW あり (92.8bpm) は、VWW なし (101.6bpm) より有意に低值を示した。 有意差は認められなかったが、PM1（99.9bpm)、PM2（99.7bpm） の心拍は、AM1 (93.5bpm)、AM2（96.4bpm）より高い傾向にあ った。

(d)活動量では、作業時間帯、VWW とも有意な差が見られなかっ たが、PM2 の平均 2.34Mets は他の時間帯に比べて $5 \%$ 程度高かっ た。一日の目標の作業量を完了するために、活動量が増えたと推定 される。鉄筋工、型枠大工の作業時間中の平均活動量は、それぞれ $2.19 \mathrm{Mets}$ 、2.36Mets で、人工気候室の模擬作業のそれぞれ $2.08 \mathrm{Mets}$ 、 $2.00 \mathrm{Mets}$ と比較すると高かった。また型枠大工の方が鉄筋工より活 動量が多かった理由として、型枠大工の作業場所が 6 階で、主に地 上での作業が多かった鉄筋工より、歩行が多かったことが挙げられ る。

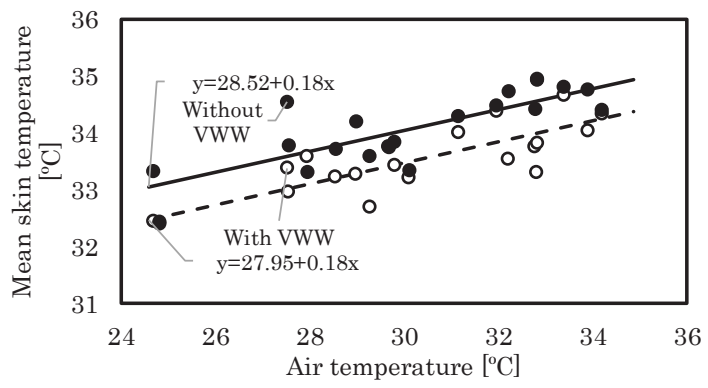

(a) Mean skin temperature

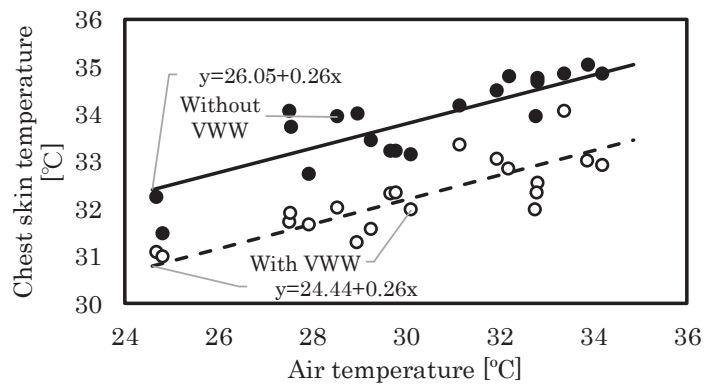

(b) Chest skin temperature

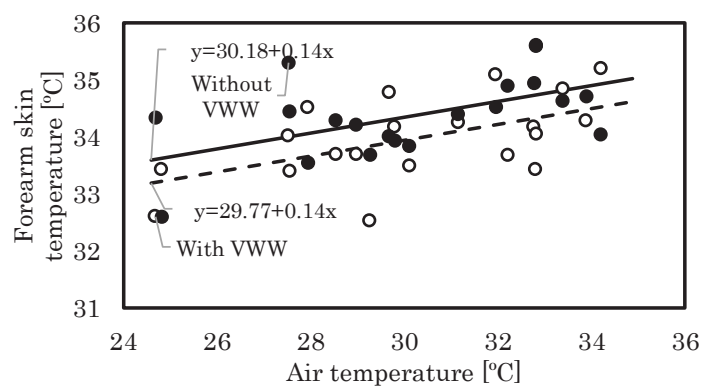

(c) Forearm skin temperature

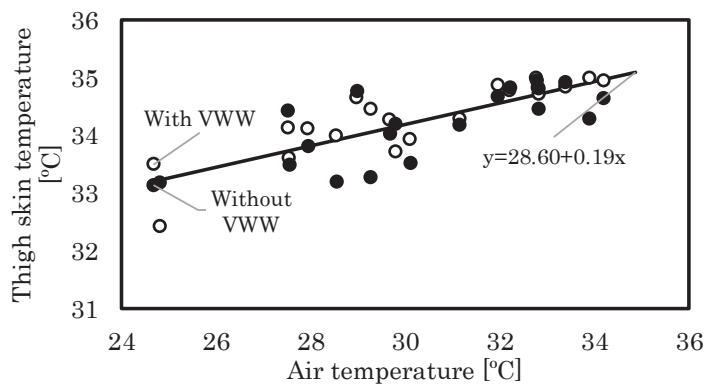

(d) Thigh skin temperature

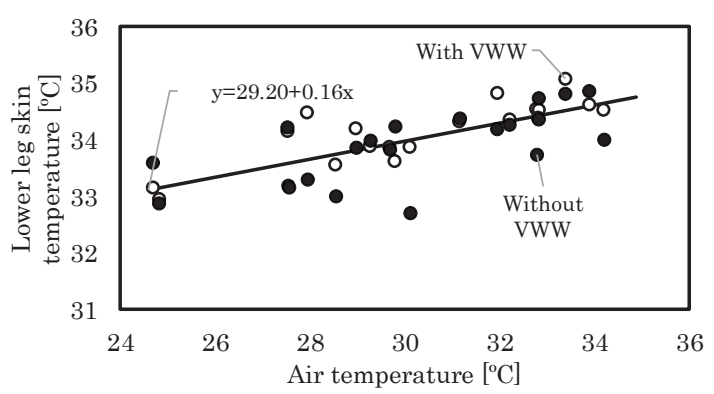

(e) Lower leg skin temperature

Fig.4 Mean and local skin temperatures

4. 考察

4. 1 蒸発密度之裸体時体重減少密度の回帰式

現場での体重減少密度を推定するために、文献 7 の土気候室実 


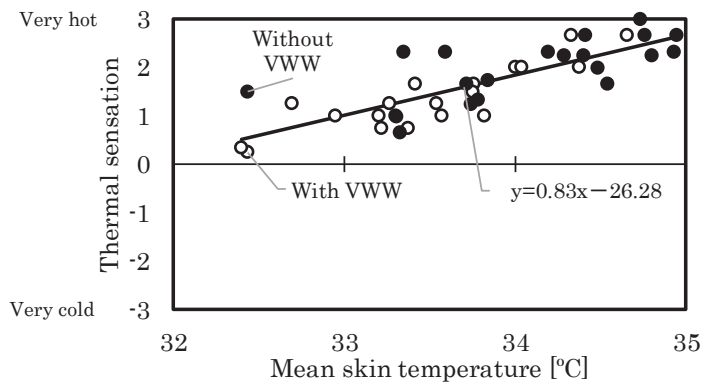

(a) Mean skin temperature vs. thermal sensation

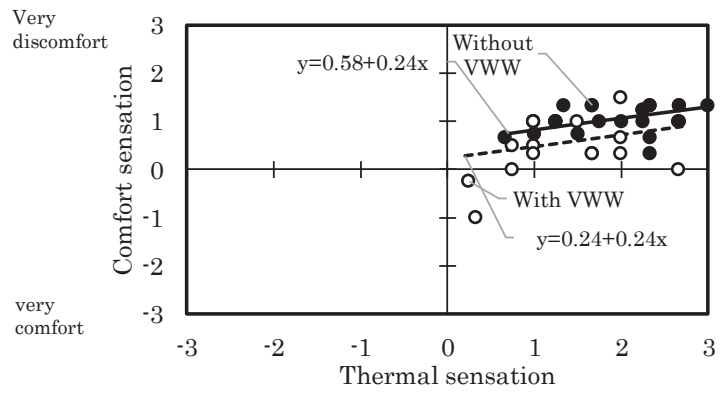

(b) Thermal sensation vs. comfort sensation

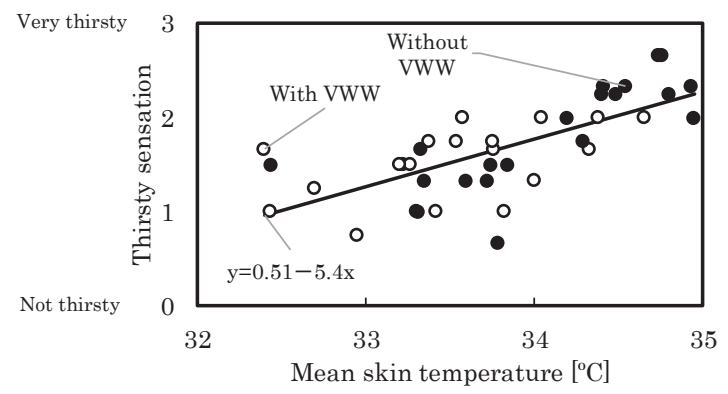

(c) Mean skin temperature vs. Thirsty sensation

Fig.5 Relation between physiological and psychological responses

験で得られた蒸発密度（文献 7 では着衣体重減少量）と裸体時体重 減少密度（文献 7 では裸体体重減少量）の関係を、VWW の有無で 直線近似した結果を示す (Fig.8)。蒸発密度と裸体時体重減少密度 の相関は高く、体重減少密度はそれぞれの回帰式を用いて、蒸発密 度から概ね求まると想定した。VWW なしに比べて、VWW ありの データはバラツキが小さく、近似直線の傾きが小さい。同じ裸体時 体重減少密度でも、VWW ありの蒸発密度は大きいことがわかる。

\section{2 現場の裸体時体重減少密度における時間帯、VWW の影響}

4.1 の回帰式を用いて、式(3)により求めた現場での蒸発密度から、 裸体時体重減少密度を推定した。

Fig.9 に、VWW と時間帯を独立変数、裸体時体重減少密度を従属 変数とした二要因の分散分析を行った結果を示す。時間帯と VWW の交互作用はないが、時間帯の主効果が有意であり $(\mathrm{F}(1,3)=5.977$, $\mathrm{p}<.001) 、 V W W$ にも主効果が認められた $(\mathrm{F}(1,1)=35.852, \mathrm{p}<.001)$ 。 Tukey の HSD 法(5\%水準)による多重比較を行った結果、AM1 と $\mathrm{PM} 2 、 \mathrm{AM} 2$ と PM2 の間に 5\%水準で有意な差が認められた。PM2 $\left(435.0 \mathrm{~g} /\left(\mathrm{h} \cdot \mathrm{m}^{2}\right)\right)$ の体重減少密度は、AM1 $\left(355.5 \mathrm{~g} /\left(\mathrm{h} \cdot \mathrm{m}^{2}\right)\right)$ 、 AM2 $\left(347.6 \mathrm{~g} /\left(\mathrm{h} \cdot \mathrm{m}^{2}\right)\right)$ より有意に高值を示した。VWW あり $\left(332.0 \mathrm{~g} /\left(\mathrm{h} \cdot \mathrm{m}^{2}\right)\right)$ は、VWW なし $\left(445.6 \mathrm{~g} /\left(\mathrm{h} \cdot \mathrm{m}^{2}\right)\right)$ より有意に 低值を示した。

\section{3 現場の気温と裸体時体重減少密度、蒸発密度の関係、裸体時体}

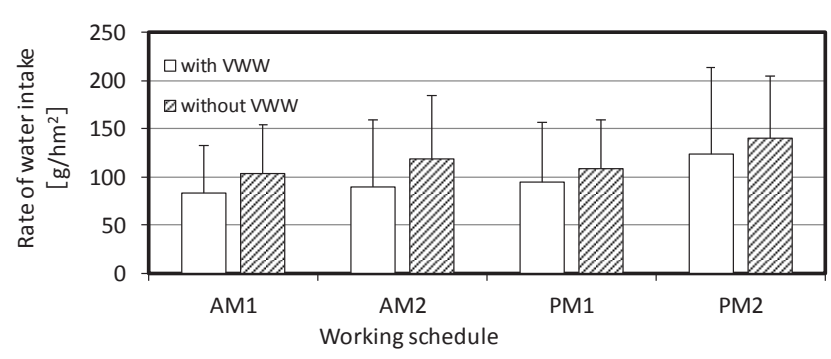

(a) Mean rate of water intake at each working schedule

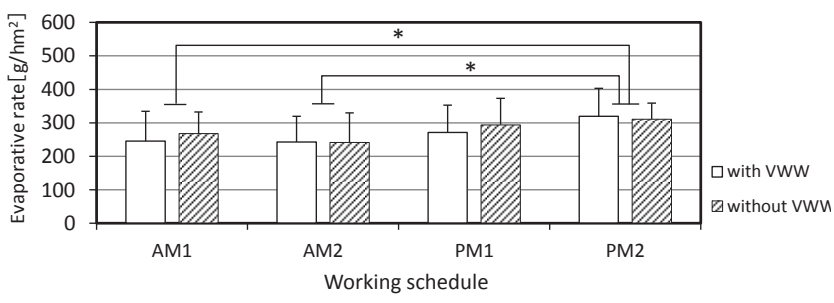

(b) Mean evaporative rate at each working schedule

Fig.6 Comparisons of mean rate of water intake, and evaporative rate with and without VWW between schedules

\section{重減少密度と飲水密度の関係におけるVWW の効果}

Fig. 10 に、気温と裸体時体重減少密度、気温と蒸発密度、体重減 少密度と飲水密度の関係をVWWの有無でプロットした結果を示す。 (a) 気温と体重減少密度の関係では、同じ気温で、VWW ありの 体重減少密度は、VWW なしょり概ね低い值に分布しており、VWW の効果が確認できた。発汗量の増大は皮膚温と深部体温の影響で決 まるので 9)、平均皮膚温をVWW が下げていた分、裸体時体重減少 密度が少なくなったと推定される。

(b)気温と蒸発密度の関係では、 (a) と異なり同じ気温の蒸発密度の VWW の有無で混在して分布しており、人工気候室実験結果 7) と同 様に、蒸発密度にはVWW の効果は認められなかった。

(c)体重減少密度と飲水密度の関係では、VWW なしは、体重減少 密度に対する飲水密度の割合が、VWW ありに比べて小さい $1 / 2$ 1/3の領域に分布しており、VWW なしは、VWW ありに比べて脱水 症状を起こしやすいと想定できる。また、一作業時間帯の飲水密度 は平均 $110 \mathrm{~g} /\left(\mathrm{h} \cdot \mathrm{m}^{2}\right)$ 程度で、平均的な体表面積 $1.8 \mathrm{~m}^{2}$ では、約 $200 \mathrm{~g} / \mathrm{h}$ 摂取しているのに対し、VWW なしでの体重減少密度は平均 $445.6 \mathrm{~g} /\left(\mathrm{h} \cdot \mathrm{m}^{2}\right)$ で、その 4 倍の約 $800 \mathrm{~g} / \mathrm{h}$ の水分を損失している。休 憩時間の飲水で、作業時間中に失った水分量の補填が重要になる。

気温 $34^{\circ} \mathrm{C}$ の工気候室の実験では、VWWにより、着衣残留汗量 と心拍数が有意に低值を示寸一方、裸体体重減少量と着衣体重減少 量にはVWW の有無で有意な差がなかった。それに対し今回の現場 実測では、24 35 $\mathrm{C} の$ 気温の範囲で、着衣残留汗量が含まれた裸体 時体重減少量（Fig.9）と心拍数（Fig.7(c)）が VWW ありで有意に 低くなるのに対し、蒸発密度（Fig.6(b)）にはVVW の効果が顕著に 認められず、人工気候室の実験と同様な結果が得られた。

本実測結果より、VWW が平均皮膚温の上昇を抑制した結果、発 汗量が抑制され脱水を予防する可能性が示唆された。しかし、午後 の作業時間、特に夕方に近い最終の PM2 の裸体時体重減少密度 （Fig.9）は、午前の AM1、AM2 に比べて有意に高く、脱水状態に 


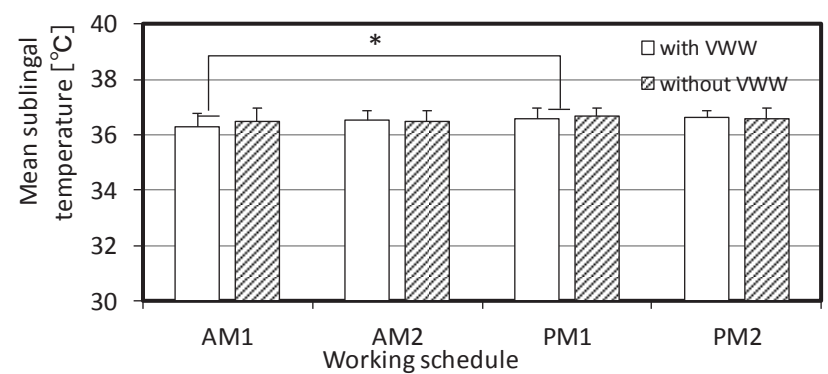

(a) Mean sublingual temperature at each working schedule

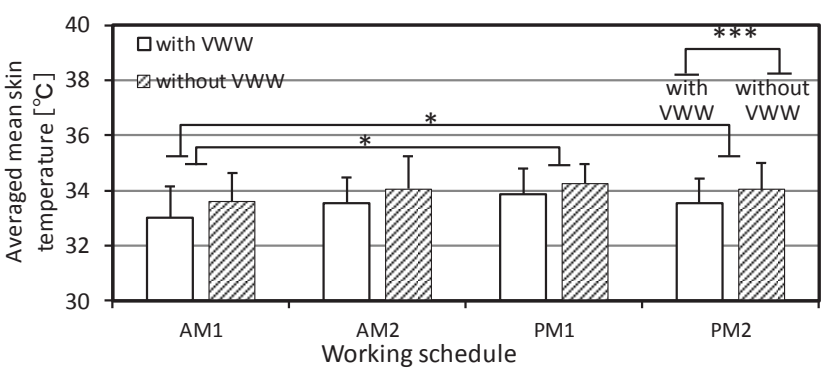

(b) Averaged mean skin temperature at each working schedule

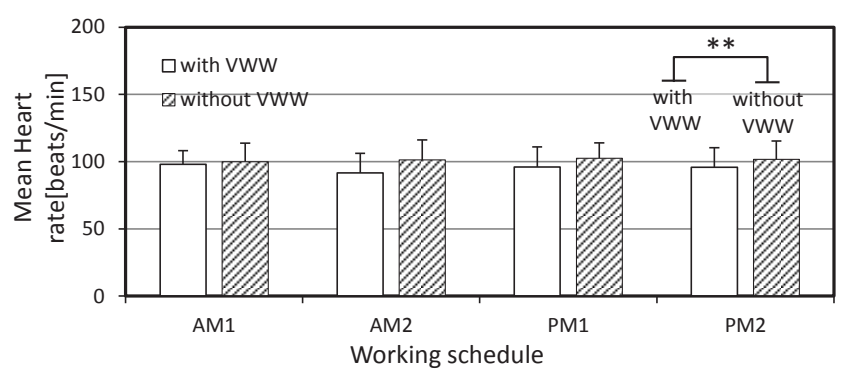

(c) Mean heart rate at each working schedule

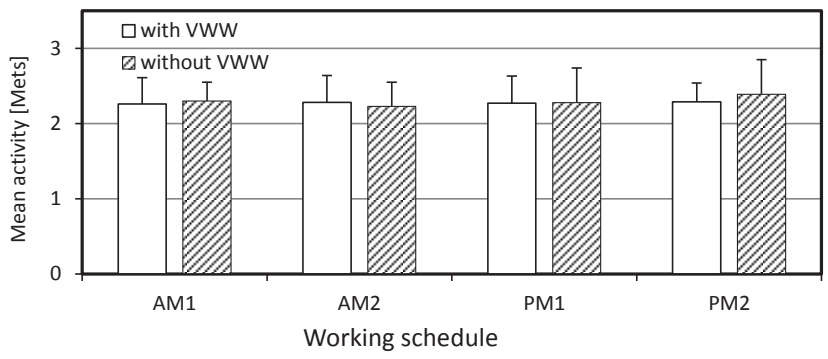

(d) Mean activity at each working schedule

Fig.7 Comparisons of mean sublingual, skin temperatures, heart rates measured at chest and mean activity with and without VWW between schedules

なりやすいと想定される。その影響で心拍数も PM2 は AM1 より $6 \mathrm{bpm}$ 程度高くなっていると、文献 7 のパスモデルからも推定でき る。この要因として、Fig.7 に示したように平均皮膚温では PM1 が $0.7^{\circ} \mathrm{C} 、 \mathrm{PM} 2$ が $0.6^{\circ} \mathrm{C} 、 そ れ そ ゙ れ ~ \mathrm{AM} 1$ に比べて高く $(\mathrm{F}(1,3)=3.899$, $\mathrm{p}<.0 .05)$ 、舌下温でも、PM1 と PM2 が、 $\mathrm{AM} 1$ に比べて $0.3^{\circ} \mathrm{C}$ 程度 高くなっていることが挙げられる（F(1,3)= 2.837, p<.05)。これに は、午後に気温が高く、風速が弱まる傾向（Fig.1）や、PM2 で作 業量がやや高め (Fig.3(d)) になることが寄与していると推定され、 今後は現状の一日を通じてほぼ一定な活動量を、午後の PM2 で小 さくしていく等の対策が必要と考えられる。

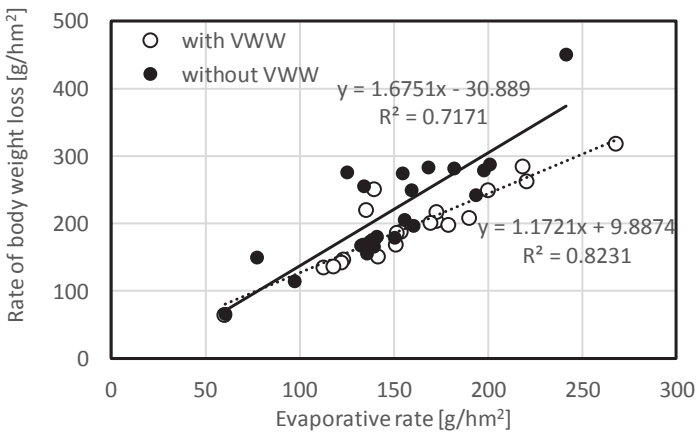

Fig.8 Relation between evaporative rate and rate of body weight loss with and without VWW measured in artificial climate chamber at two fixed temperatures $\left(29,34^{\circ} \mathrm{C}\right)$.

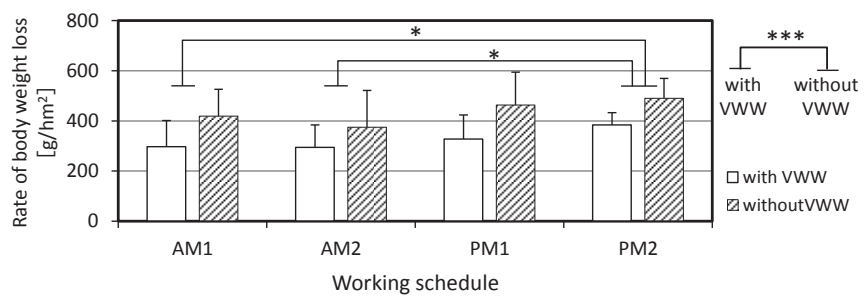

Fig.9 Comparisons of mean rate of body weight loss with and without VWW between schedules

\section{5.まとめ}

本研究では、実際の建設現場において VWW や作業時間帯が皮膚 温や体重減少量等に及ぼす影響を検証することを目的として現場実 測を行った。実測期間 5 日間のうち、8月 3,4 日は気温が $30^{\circ} \mathrm{C}$ 以下、

$5,7,8$ 日は気温が $30^{\circ} \mathrm{C}$ を超える環境であった。

気温と皮膚温の関係について、回帰直線の差の検定を行った。平 均皮膚温、胸部温、前腕温は、VWW ありよりもVWW なしの皮膚 温の方が有意に高くなった。既報の諸条件が統制された人工気候室 の $34^{\circ} \mathrm{C}$ の環境でも、平均皮膚温、胸部温については、VWW ありが VWW なしょり有意に低かったが、前腕温は、VWW なしと VWW ありで有意差が見られなかった。これは、現場での VVWを着用す ることによる日射遮蔽の影響に起因すると考えられた。

一方、平均皮膚温と暑さ感の関係は、検定の結果、VWW の有無 で有意差は見られなかった。暑さ感と快適感の関係では、有意な差 が見られ、VWW があることにより同じ暑さ感でも不快感はやや軽 減されることが明らかとなった。

気温と蒸発密度の関係では、蒸発密度にはVWWの効果は認めら れなかった一方、気温と裸体時体重減少密度の関係では、同じ気温 でも、VWW ありの体重減少密度は、VWW なしょり概ね低い值に 分布しており、VWW の効果が確認できた。以上のように、皮膚温、 蒸発密度・体重減少量等の発汗量についての諸条件を統制して得ら れた人工気候室での実験結果は、現場の実測によりほぼ妥当性が検 証され、現場でも適用できると考えられた。しかし、上記パラメー 夕における VWW の効果は、現場では $24^{\circ} \mathrm{C} \sim 35^{\circ} \mathrm{C}$ のぼ全体の気 温の範囲で認められたのに対し、人工気候室での実験では気温 $34^{\circ} \mathrm{C}$ でしか認められなかった。この要因としては、実際の現場の作業員 の活動量が、模擬作業の実験室の活動量より高めで、かつ作業員が、 


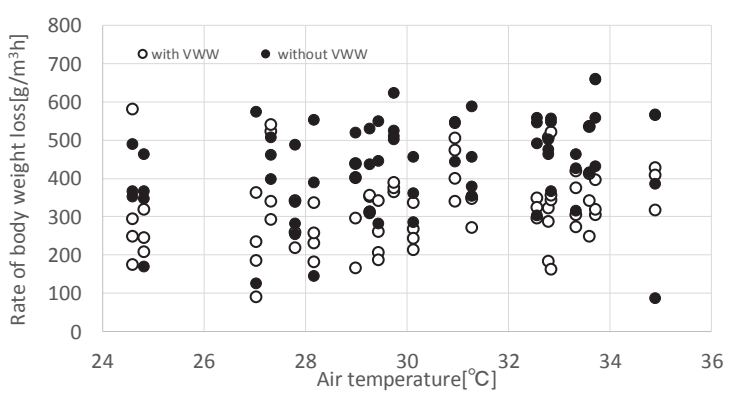

(a) Relation between air temperature and rate of body weight loss

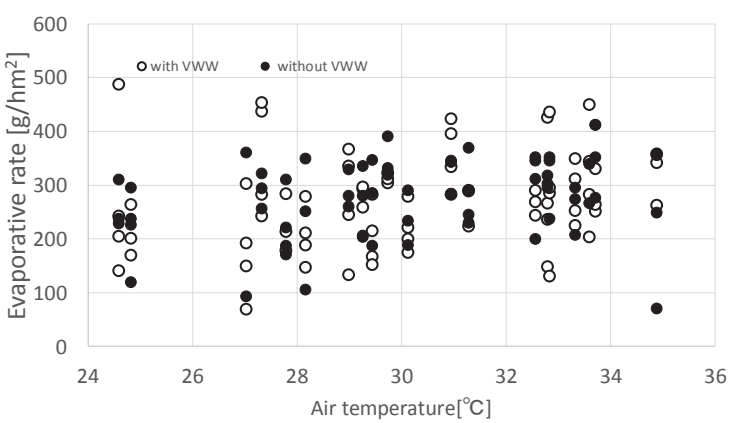

(b) Relation between air temperature and evaporative rate

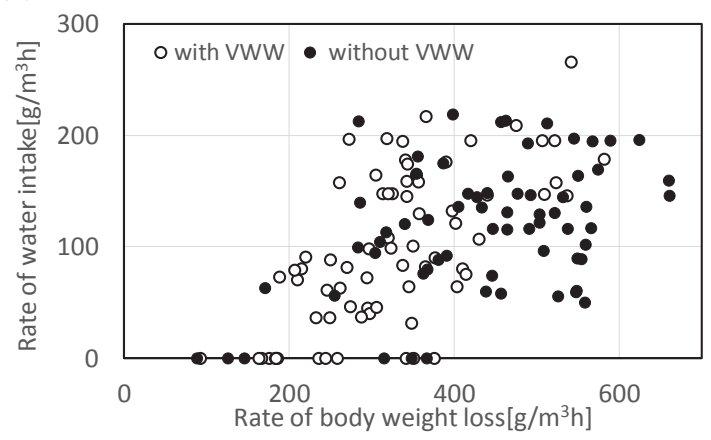

(c) Relation between body weight loss and rate of water intake

Fig.10 Verifications on effect of VWW on rate of body weight loss, evaporative rate and rate of water intake.

人工気候室と異なり、温度が上昇した地物面と日射を含めた熱放射 の影響を受けていたことが原因と推察される。

午後の作業時間、特に夕方に近い最終の PM2 の裸体時体重減少 密度は、午前と比べて有意に高く、脱水状態になりやすいと推定さ れ、その影響で心拍数も午後は AM1 より高くなっている。また、 平均皮膚温や舌下温も午後が、AM1 に比べて高くなっている。これ は、午後に温熱環境が悪化することや、PM2 でやや高めの作業量に なっていることが寄与していると推定され、現状の一日を通じてほ ぼ一定な活動量を、午後の PM2 で小さくしていく等の対策が必要 と考えられる。

\section{謝辞}

実験にご協力頂きました被験者の皆様、現場実測にご協力頂きま した株式会社竹中工務店東京本店作業所の皆様と株式会社竹中工務 店技術研究所の北村岳氏、現場実測とデータの解析にご協力頂きま した大前裕紀氏 (研究当時北海道大学大学院工学院修士課程)、金内 遥一朗氏 (北海道大学大学院工学院修士課程)、小林明生氏 (研究当 時岩手大学理工学部生) に感謝の意を表します。
1) Nishihara, N., Tanabe, S., Hayama, H., Komatsu, M.: A Cooling Vest for Working Comfortably in a Moderately Hot Environment. Journal of PHYSIOLOGICAL ANTHROPOLOGY and Applied Human Science, Vol 21, No. 1, pp. 75-82, 2002. 1

2) Gao, C., Kuklane, K., Holmér, I.: Cooling vests with phase change material packs: the effects of temperature gradient, mass and covering area. Ergonomics, Vol. 53, No. 5, pp. 716-723, 2010. 5

3) Zhao, M., Gao, C., Wang, F., Kuklane, K., Holmér, I., Li, J.: A study on local cooling of garments with ventilation fans and openings placed at different torso sites. International Journal of Industrial Ergonomics, Vol. 43, No. 3, pp. 232-237, 2013. 5

4) Miura, K., Takagi, K., Ikematsu, K.: Evaluation of two cooling devices for construction workers by a thermal manikin. Fashion and Textiles, Vol. 4, Issue. 1, 23, 2017. 11

5) Chan, A.P.C., Zhang, Y., Wong, F.F.K., Chan, D.W.M., A field study of the effectiveness and practicality of a novel hybrid personal cooling vest worn during rest in Hong Kong construction industry. Journal of Thermal Biology, Vol. 70, Part A, pp. 21-27, 2017. 12

6) Yamazaki, K., Suga, S., Takahashi, N., Kuwabara, K., Kobayashi, K. The Psychological and Physiological Effects of Air-conditioned Wear and Other Functions on Construction Workers, No.1 Actual Investigation at Active Construction Site. Journal of Environmental Engineering (Transactions of AIJ), Vol. 83, No. 747, pp. 453-463, 2018. 5 (in Japanese)

山㠃慶太，菅重夫，高橋直，㭉原浩平，小林宏一郎：ファン付き作業服が建 設作業員の生理・心理反応に及ぼす影響と他の要因に関する研究, 建設現 場における実態調査その 1 , 日本建築学会環境系論文集, 第 83 巻, 第 747 号, pp. 453-463, 2018. 5

7) Yamazaki, K., Suga, S., Kuwabara, K., Hamada, Y., Syu, S., Nakano, R., Kobayashi, K. and Takahashi, N., Effect of Simulated Work in Artificial Climate Chamber on Physiological and Psychological Responses of Construction Workers with Air-Conditioned Wear, Journal of Environmental Engineering (Transactions of AIJ), Vol. 83, No. 748, pp. 543-553, 2018. 6 (in Japanese)

山崎慶太，菅重夫，葉原浩平，濱田靖弘，朱楚奇，中野良亮，小林宏一郎， 高橋直，人工気候室での模擬作業がファン付き作業服を着用した建設作業 員の生理・心理反応に及ぼす影響, 日本建築学会環境系論文集, 第 83 巻, 第 748 号, pp. 543-553, 2018. 6

8) Kuwabara, K., Kubota, H., Hamada, Y. et al., Prediction of Mean Skin Temperature in Hot Outdoor Environment considering Sweat Efficiency and Wet Clothing, Vol. 34, No. 144, pp. 1-10, 2009. 3 (in Japanese) 葉原浩平, 窪田英樹, 濱田靖弘, 中村真人, 中谷則天, 雨宮智史, 長野克則, 無効発汗・着衣のぬれを考慮した屋外環境における平均皮膚表面温度の予 測, 空気調和・衛生工学会論文集, Vol. 34, No. 144, pp. 1-10, 2009. 3

9) Nadel, E.R., Bullard, R.W., Stolwijk, J.A.J., Importance of skin temperature in the regulation of sweating. Journal of Applied Physiology, Vol. 31, No. 1, pp. 80-87, 1971. 7

注

注1）作業中の便所利用は記録しているが、尿量は測定していない。作業中の タオル使用も許可したが、タオルに含まれた汗量は測定していない。休 熄中の飲水や食事に制限は設けず、作業員は主に $30^{\circ} \mathrm{C}$ 以下に空調され

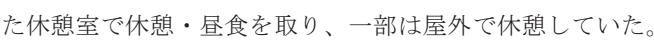

注2）実験時は、1 を非常に暑い、7 を非常に寒い等としていたが、本報では Table5 のように数值を-3〜+3 に置き換えて示すこととした。

注3）単位の METs は安静時の酸素摂取量 $V_{\mathrm{O} 2}=3.5[\mathrm{~mL} / \mathrm{kg} / \mathrm{min}]$ を $1 \mathrm{METs}$ と して、現在の作業が何倍に当たるかを表したものであるのに対し、単位 met は人体と環境との間の熱平衡式で用いられる椅座安静時の代謝量

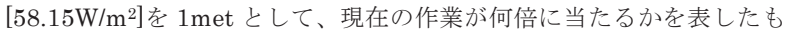
のである。met の計算には $V_{O 2}$ と呼吸商 $R$,体表面積 $A_{D u}$ が必要である ため、本報では $A_{D u}=1.8 \mathrm{~m}^{2}$ （身長 $1.7 \mathrm{~m}$, 体重 $70 \mathrm{~kg}$ ）, $R=0.92$ と仮定し た場合の代謝量[met]を表している。 


\title{
EFFECT OF VENTILATED WORK WEAR AND WORKING SCHEDULE ON PHYSIOLOGICAL AND PSYCHOLOGICAL RESPONSES OF CONSTRUCTION WORKERS
}

No.2 Actual investigation at active construction sites

\author{
Kouhei KUWABARA ${ }^{* 1}$, Keita YAMAZAKI*2, Shigeo SUGA ${ }^{* 3}$, \\ Koichiro KOBAYASHI ${ }^{* 4}$, Yasuhiro HAMADA ${ }^{* 5}$ and Nao TAKAHASHI ${ }^{* 6}$ \\ ${ }^{* 1}$ Assoc. Prof., Dept. of Creative Engineering, National Institute of Technology, Kushiro College, Dr.Eng. \\ *2 Assist. to General Manager, Takenaka Research \& Development Institute, Dr.Eng. / Visiting Prof. of Iwate University \\ *3 Takenaka Corporation, Head Office, Tokyo, Safety and Environment Dept. \\ ${ }^{* 4}$ Prof., Dept. of Systems Innovation Engineering, Iwate University, Dr.Eng. \\ ${ }^{* 5}$ Prof., Graduate School of Engineering, Hokkaido Univ., Dr.Eng. \\ ${ }^{* 6}$ Chimura Nature Club, Ph.D. in Sociology
}

To verify the effects of wearing ventilated work wear (VWW) on the physiological and psychological responses of construction workers (CWs), measurements were carried out on workers at an eight-story building in an RC construction in Tokyo from August 3-8, 2017. Air temperature, relative humidity, air velocity, and black and white globe temperatures were measured on the ground floor, while air temperature, relative humidity, air velocity, and solar radiation were measured on sixth floor. The heights of the thermo-hygrometer, anemometer, and globe thermometer were about 1.5, 2.0, and $1.0 \mathrm{~m}$ off the ground, respectively. The study participants were four male form workers and three male rebar placers ranging in age from their 20s to 60s. Their work is basically carried out from 08:00 to 17:00 and is divided into four shifts split up by breaks as follows: AM1: 8:00 to 10:00; AM2: 10:30 to 12:00; PM1: 13:00 to 15:00; and PM2: 15:30 to 17:00. The heart rate (HR) and skin temperatures for the chest, forearm, thigh, and lower leg were continuously measured, and sublingual temperature, body weight, water intake, and psychological responses, such as hotness, comfort, and thirst, were measured before and after each working hour. We defined the evaporation rate (ER) as the sum of the difference in body weight while fully clothed between before and after work and the amount of water intake (WI) per unit time and body surface area. The rate of body weight loss (BWL), defined as the sum of the sweat and evaporation rates by skin diffusion, at the construction site (CS) was simulated according to a regression formula between the ER and BWL obtained from an experiment involving humans in an artificial chamber (AC). We evaluated the effect of wearing/not wearing VWW and working schedule on physiological responses. Air temperature was below and above $30^{\circ} \mathrm{C}$ until August 4 and after August 5, respectively. The mean overall and both chest and forearm skin temperatures were significantly higher in the workers not wearing VWW compared with those who were wearing VWW. In the AC experiment, no significant differences were observed in forearm skin temperature between workers wearing/not wearing VWW. The lower forearm skin temperature observed among workers at the CS was likely the result of the VWW preventing solar radiation from being absorbed on the skin surface. The HR (101.6bpm) of workers not wearing VWW was significantly higher than that of workers wearing VWW (92.8bpm). No significant differences were observed in the ER or WI between the two groups. On the other hand, BWL $\left(445.6 \mathrm{~g} /\left(\mathrm{h} \cdot \mathrm{m}^{2}\right)\right) \mathrm{among}$ workers not wearing VWW was significantly higher than that among workers wearing VWW $\left(332.0 \mathrm{~g} /\left(\mathrm{h} \cdot \mathrm{m}^{2}\right)\right)$. In addition, wearing VWW at the CS alleviated discomfort. These results suggest that VWW helps prevent dehydration during work because the lower mean skin temperatures resulting from wearing VWW suppress BWL. The mean skin temperatures in the PM1 $\left(34.05^{\circ} \mathrm{C}\right)$ and $\mathrm{PM} 2\left(33.91^{\circ} \mathrm{C}\right)$ were significantly higher than those in the AM1 $\left(33.30^{\circ} \mathrm{C}\right)$. The HR of the PM workers was slightly higher than that of the AM workers; however, this difference was not significant. The activity level (2.34METs) in the PM2 was about 5\% higher than that in the AM and PM1. The ER $\left(315.2 \mathrm{~g} /\left(\mathrm{h} \cdot \mathrm{m}^{2}\right)\right)$ in the PM2 was significantly higher than that in the AM1 $\left(256.8 \mathrm{~g} /\left(\mathrm{h} \cdot \mathrm{m}^{2}\right)\right)$ and AM2 $\left(242.5 \mathrm{~g} /\left(\mathrm{h} \cdot \mathrm{m}^{2}\right)\right)$. In addition, BWL in the PM2 $\left(435.0 \mathrm{~g} /\left(\mathrm{h} \cdot \mathrm{m}^{2}\right)\right)$ was significantly higher than that in the AM1 $\left(355.5 \mathrm{~g} /\left(\mathrm{h} \cdot \mathrm{m}^{2}\right)\right)$ and AM2 $\left(347.6 \mathrm{~g} /\left(\mathrm{h} \cdot \mathrm{m}^{2}\right)\right)$. Since the thermal environment deteriorates and activity levels slightly increase in the afternoon, CWs in the PM2 may be at a higher risk of dehydration; therefore, to help prevent dehydration, CWs in the PM2 should have a reduced workload. 